\title{
碞翟
}

ISSN: 2474-3542 Journal homepage: http://journal.calaijol.org

\section{eBook Service in Shanghai Library}

\section{Qing Zhou}

\begin{abstract}
:
In the 21st century, with the rapid development of mobile Internet, people's reading habits have started shifting from the traditional paper-based media, to completely new media such as cell phones, eBook readers, tablet PCs and so on. "Shanghai Library's Urban Digital Reading Service Platform" integrates all types of collections of digital resources to support eBook readers, tablet PCs, smart phones and other types of mobile devices. This platform provides a convenient, low-cost and friendly learning interface to online users, providing one of the best reading experiences. This also creates a one-stop public library reading platform, and meets the reader's need for reading on the go. By investigating and researching libraries' experiences and requirements for digital reading platforms and its internationalization service, this paper will discuss its further development.
\end{abstract}

To cite this article:

Zhou, Q. (2016). eBook service in Shanghai Library. International Journal of Librarianship, 1(1), 66-73. https://doi.org/10.23974/ijol.2016.vol1.1.16

To submit your article to this journal:

Go to http://ojs.calaijol.org/index.php/ijol/about/submissions 


\title{
eBook Service in Shanghai Library
}

\author{
Qing Zhou \\ Shanghai Library, Shanghai, China
}

\begin{abstract}
In the 21 st century, with the rapid development of mobile Internet, people's reading habits have started shifting from the traditional paper-based media, to completely new media such as cell phones, eBook readers, tablet PCs and so on. "Shanghai Library's Urban Digital Reading Service Platform" integrates all types of collections of digital resources to support eBook readers, tablet PCs, smart phones and other types of mobile devices. This platform provides a convenient, lowcost and friendly learning interface to online users, providing one of the best reading experiences. This also creates a one-stop public library reading platform, and meets the reader's need for reading on the go. By investigating and researching libraries' experiences and requirements for digital reading platforms and its internationalization service, this paper will discuss its further development.
\end{abstract}

Keywords: eBooks service, Shanghai Library, internationalization service, public libraries

\section{INTRODUCTION}

Humans have never stopped in their pursuit for knowledge. As technology leaps forward, the content carriers for human reading known as "books", have turned from materials like bones, sheepskins, and bamboo slips into what we now know today as paper. However, in 1971, a new format to challenge the paper-based book was born. It is the eBook. eBooks have revolutionized the traditional human reading habits. In the 21 st century, with the rapid development of mobile Internet, people's reading habits have started shifting from the traditional paper-based media, to completely new media such as cell phones, eBook readers, and tablet PCs. (Zhang, 2015) In China, almost all the major network booksellers and book publishing groups have launched eBook sales services. Under this model, the traditional library is being transformed to better meet the diverse multi-leveled needs of its readers, and is learning to provide public services with its rich eBook resources in the electronic environment.

At the end of the last century, Shanghai Library purchased the Rocket eBook (Figure 1), manufactured by NuvoMedia and the SoftBook (Figure 2) which is designed by IDEO and Lunar Design. These proved to be the first step for providing eBook services in China. Since the beginning of the 21 st century, the Shanghai Library has provided remote access to digital library resources. However, because of factors such as low awareness and high learning curves, this service was not well used. Therefore, creating the e-book reading platform on our own has become a viable option. 


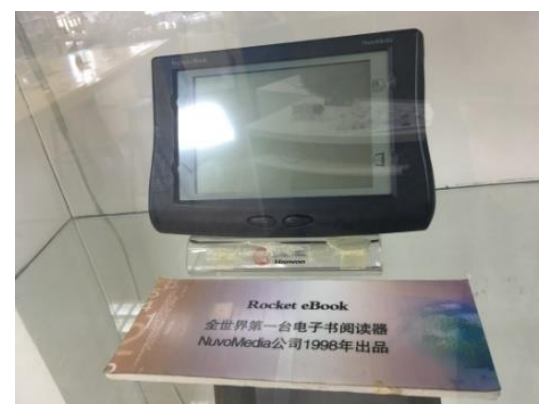

Figure 1. Rocket eBook

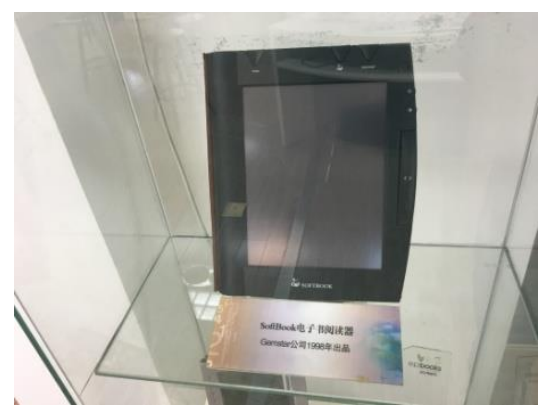

Figure 2. SoftBook

\section{SHANGHAI LIBRARY AND ITS SERVICES}

Shanghai is the largest city in China. It is the center of economy, finance, trade and shipping in mainland China. (The State Council Information Office of the People's Republic of China, 2009). The city "also holds a leading place in China's arts, sciences and education. ... its first library dates to 150 years ago". (Shanghai Library, n. d., para. 1) Shanghai Library was founded in 1952. Six years later, it became the second largest comprehensive public library in China after merging with three other libraries in Shanghai. In 1995, the Institute of Scientific and Technological Information of Shanghai was merged with Shanghai Library, "resulting in an advanced, comprehensive public library, the first ever in the country that combines public library services with SciTech and industry research information functions". (Shanghai Library, n. d., para. 7)

The library information system at Shanghai Library supports two platforms: one is the "one-cardthrough" information system platform of the Shanghai Central Library; and another is the Shanghai information service platform. The "one-card-through" information system fully covers all district and county and neighborhood libraries in Shanghai. It links nearly 250 libraries and more than 280 service stations in the city. The system contains over 9.3 million books and circulates 36.76 million items each year. It has 686,000 active users. With the application of RFID technology in recent years, many branches provide self-registration and self-check services. Shanghai Library also provides online search or access to rare books, manuscripts, genealogy resources, archives, books and journals. Its online system contains 3.79 million metadata records and 45.9 million full-text pages. The library has become one of the largest self-built digital repositories in China. Additionally, the library automation systems implemented in Shanghai Library enables the library to open 365 days in a year. (Shanghai Library, n. d.) 


\section{EBOOK SERVICE IN FOREIGN PUBLIC LIBRARIES}

Digital library reading services have existed for a long time. Foreign libraries, with its early adoption and rapid development, have already formed a mature industry chain constituted by publisher, third-party service provider, library and the user.

(1) United States: Regarding eBook lending policies, the United States library community attaches great importance to the interests of user's right to eBook lending services, and therefore provides free eBook lending services under policy agreements, reached with the cooperation of large eBook dealers such as OverDrive and 3M. Among the dealers, the OverDrive eBook platform is capable of storing resources from more than 1,000 publishers all over the world, and is compatible to most resource formats, supportive for tablet PCs, smart phones and other devices since it adopts many open resource formats. Flexibility of copyright policy is also one of OverDrive's highlights, which provides personalized DRM scheme for different publishers, and enables the library to formulate suitable lending policies for different readers. This compatibility with multiple devices and flexibility in copyright policies creates gains for Overdrive's global popularity ratings and promoted usage statistics (Fu and Huang, 2012).

(2) UK: In 2012, William Sieghart was appointed by The Department of Culture, Media and Sport as well as an expert group composed of The Society of chief Librarians, the publishing industry, booksellers and authors to conduct an "independent review of E-lending in public libraries in England." This review aimed to establish some basic parameters, business test models and user behavior, so that it could contribute to the newly formed agreement between publishers and libraries to jointly promote digital lending. (Sieghart, 2015). In March 2014, The Society of chief Librarians and the Publishers Association announced the official launch of a 12-month remote eBook lending pilot project. (Price, 2015). The project greatly contributed to eBook lending, and the popularity of the titles offered, compared to the existing library collections. Lastly, this pilot project attracted some new borrowers (The Publishers Association, 2015).

\section{EBOOK SERVICE IN SHANGHAI LIBRARY}

Figure 3 shows that the penetration rate of mobile Internet users for information and reading reaches $59.1 \%$. Reading is one of the most popular types of mobile applications visibly.

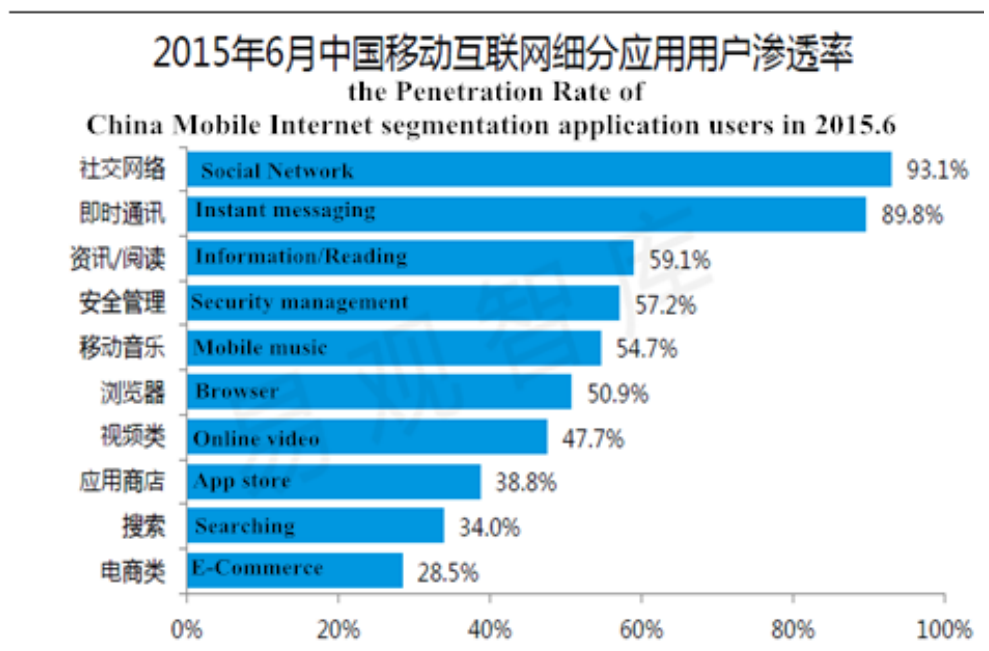

Figure 3. The Penetration Rate of Mobile Internet segmentation application users in China in June 2015 (Analysys Yiguan, 2015, p.6) 
Figure 4 shows that the mobile reading market covers 178 million people in China in the third quarter of 2015. The Twelfth National Reading Survey issued by the Chinese Academy of Press and Publication (as cited in Zhang and Zhang, 2015) indicates that the frequency for Chinese digital reading was $58.1 \%$, increased eight percentage points, compared with 2013, and for the first time, digital reading rate exceeded the traditional reading rate. The data shows that China's eBook reading demand is growing rapidly, and the digital market has great potential for development. Although China's eBook industry chain matures day by day, China is still in need of a similar mature eBook platform for libraries, such as the US OverDrive eBook platform. The US libraries tend to use the eBook platform to show off its eBook collections, so the network promotion of eBooks is highly tied to the eBook database and the way it is built. However, in China, most of our libraries normally provide only the link to the eBook, therefore missing the chance to show the description and integration of various bibliographic resources.

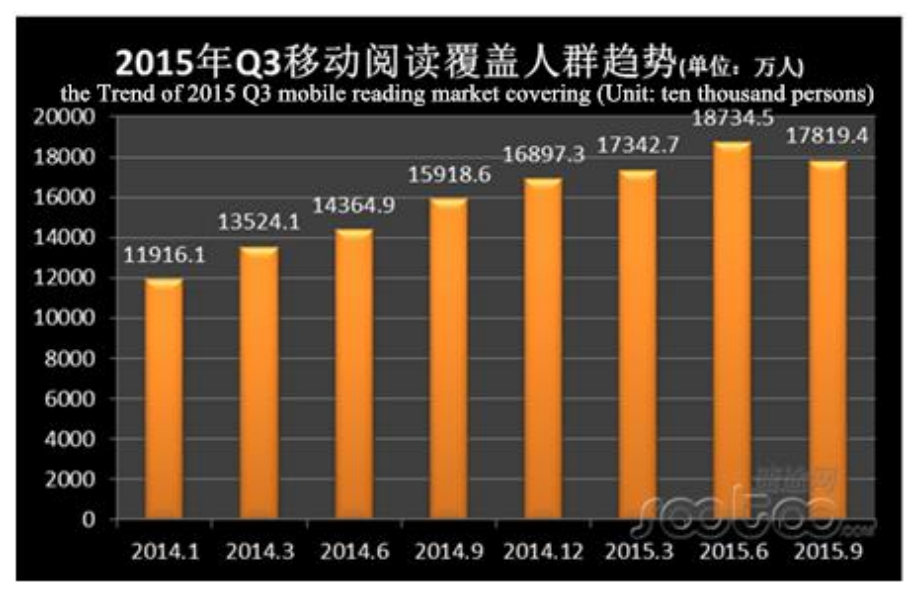

Figure 4. The Trend of 2015 Q3 mobile reading market covering (Sootoo Institute, 2015, para.4)

In December 2011, the Shanghai Library launched the public digital reading promotion program, to bring awareness to the eBook reader experience and lending, digital resource construction, and many other contents (Zhang, 2015). The Shanghai Library's Urban Digital Reading Service Platform integrates all types of collections of digital resources to support eBook readers, tablet PCs, and smart phones, so as to provide a convenient, low-cost and friendly learning interface to users and the best reading experience. Furthermore, this creates a one-stop public library reading platform to meet the reader's need for convenient reading in any environment. After years of exploration and research, it has grown into a digital reading oriented resource integration platform, different from the ordinary resources navigation platform $(\mathrm{Li}, 2015)$. Through deep integration of various eBook library resources, it achieves the seamless connection between front-end browsing and backend resources and can support a variety of display modes such as website, APP, micro-website, providing reader service through a variety of devices (Zhang, 2015).

\section{INNOVATIONS OF SHANGHAI LIBRARY EBOOK SERVICE}

With increasingly rich digital resources, the "Window of Shanghai" has launched a new eBook service to its global partners apart from traditional paper books. This service model breaks the traditional eBook borrowing system, and forms a new norm for international eBook services.

\section{Opening of the "Window of Shanghai" eBook Web Service}

In 2013, on the homepage of the "Window of Shanghai" program of Shanghai Library, an "eBook" 
button first appeared, marking the official launch of the "Window of Shanghai" eBook service website. The "Window of Shanghai" eBook service works with its global partners with the intention to provide the overseas reader a more convenient, easy to access way to the latest publications from China. In recent years, the electronic resource service has grown in popularity thanks to the vigorous overseas promotion of eBooks from the Intercontinental Press, Penguin Press and other domestic publishing house. eBook subjects cover China and Shanghai's contemporary history, economy, character, philosophy, literature, culture and folk traditions, history, nature and cultural landscape, culinary arts, traditional Chinese medicine, architecture and a variety of other subjects. eBooks are mainly in Chinese, English or bilingual (English/Chinese), meanwhile in order to suit the needs of readers from different linguistic regions, over 10 other languages are also included, for example French, Russian, and Japanese, just to name a few. The same kind of problem is encountered by both domestic and foreign libraries: the technology platform and file format provided by eBook publishers to libraries are not the same, and this common inconsistency in library electronic lending services leads to the library's failure to integrate digital resources from different vendors. It furthermore reduces the visibility of eBook resources, and results the user's inability to take full advantage of digital library resources. However, during the internationalization process of this eBook service, the Shanghai Library followed the example of the free eBook lending service cooperatively developed by OverDrive and 3M. In this model, OverDrive and 3M constantly look to integrate the contents of eBooks and formats, according to the needs of its partners, users and projects. The current "Window of Shanghai" service has expanded its offerings from the original 1,280 ebooks to 10,059 eBooks, 227 reference books, 30 newspapers and 7,000 Chinese digitized journals.

\section{International Specifications of the "Window of Shanghai" eBook Service Website}

Via IP authentication and account authorization, the website provides exclusive "My library" services, collections, and recommendations for its partners. Due to the characteristic of foreign exchange and cooperation, the website establishes an eBooks query and navigation system in 17 languages, covering the world's most common languages for the convenience of the multilingual reader. Apart from the fact that the website can automatically display Simplified Chinese, Traditional Chinese and English sections according to the operating system language, it also offers diverse full-page translation. In 2015, besides the existing IP registration mode, the "Window of Shanghai" again opened 300 eBook accounts as gifts to readers around the world. With these accounts and their matching passwords, readers can now experience a different way to read instead of going to the library. As long as a connection is established, they can log into the "Window of Shanghai" eBooks website, making full use of its services, and enjoy digital reading anytime, anywhere. By the end of October 2015, this service has been trialed with 26 library partners. In order to provide readers and its partners a more convenient searching eBook platform, the "Window of Shanghai", can, by collecting and analyzing the website usage data, combine the recommendations of new books, topics and top book reads in its resource recommendation. New books on e-shelves are displayed on the homepage for the reader to get a sense of the new eBooks available. According to user feedback from the recipient libraries of this service, the "Shanghai Window" also creates a more dynamic process in which the system analyses reader preferences to build upon its collection, being able to organize it into relevant themes.

\section{Statistical Data Highlighting the Internationalization Achievements of the "Window Of Shanghai" eBook Service}

From Table 1, we can see that in 2014, the number of visits to the site is six times that of the year 2013, creating a significant rise in awareness and the visits for the year 2015 more than 1.5 times that of the whole year in 2014. As for retrievals and/or searching, the retrievals number of the year 
2014 is 18 times that of the year 2013, showing an obvious upward trend. The retrieval number for 2015 of use is above 2 times that of the whole year for 2014. When one looks at the numbers for online reading, the full-year number of 2014 is three times that of the 2013, again showing a rising trend. Also, the number of online reading in 2015 seems much more than the year 2014.

\begin{tabular}{|c|c|c|c|c|}
\hline Year & Access & Retrieval & Online Reading & Circulation \\
\hline 2013 & 8,645 & 363 & 7,104 & 6 \\
\hline 2014 & 52,598 & 6,773 & 26,535 & 25 \\
\hline 2015 & 84,879 & 14,509 & 29,113 & 63 \\
\hline
\end{tabular}

Table 1. Statistical data of the eBook service

The "Window of Shanghai" service has been maintaining a good relationship with its partners around the world, and it may also be a good idea to bridge lateral communication opportunities between the various partners, so that libraries around the world and related publishing houses can get to know each other and explore the possibility of cooperation with support from the "window of Shanghai" platform. Consequently, the "Window of Shanghai" can be further internationalized, by becoming a program with a wide coverage of global partnerships in the library community. The "Window of Shanghai" eBook website's grass-roots development in platform and content, as well as its growing users base, shows clearly that the service is gradually maturing. The "Window of Shanghai" eBook service can become the model platform for displaying and exchanging content along with cooperating between domestic and international libraries, as well as how its readers interact with the service.

\section{CONCLUSION AND RECOMMENDATION}

The "smart device" has been achieving breakthroughs in its popularity especially in the wake of mobile Internet. Mobile applications have become the new way to use the internet as the global mobile population is also growing rapidly. Mobile internet applications are changing people's way of communicating and reading, and are profoundly changing our lives. Therefore, the focus of further developing the internationalized eBook service of Shanghai Library will be to provide a high quality and essential mobile reading service. A few suggestions from the author can be proposed as follows:

(1) Introduce digital copyright technology into cross-border eBook lending policies. Accelerate the setting of eBook standards, and set up an eBook standards working group to jointly formulate industrial and national standards concerning eBook formats, quality, platforms, copyright etc. so as to create a framework for e-book library lending policies.

(2) Integrate the eBook lending system, the OPAC collection and open access resources. The eBook lending function and the integrated OPAC system of the Shanghai Library should still be improved. (Wei and Liu, 2015)

(3) The library is one of the most powerful drivers in the extensive use of eBooks [10. The ultimate purpose for enhancing eBook lending services is to make wider use of eBooks. Therefore, the library should take on the responsibility to improve the utilization of eBooks. Without the participation and support of this crucial issue, the development of electronic lending could be unsustainable. Libraries and various interested groups, such as eBook publishers or e-reader 
manufacturers should jointly discuss and explore terms of reference for eBook license agreements, promoting the development of electronic lending services.

(4) The popularity of smart phones and other mobile applications shows the shifting trend to mobile reading. (Shen, 2015) As a new concept in mobile Internet era, micro-website is the basic application platform and mobile portal for enterprises, and also a unified data entrance for the mobile Internet. This platform can integrate online inquiry system, digital reading, event publisher, service portals and other platforms, and at the same time be extended to a variety of mobile applications. In future, promoting micro-website to overseas partners would become possible. The Shanghai Library, with its welcoming and positive attitude to Internet + , connections among everything, creates a new model of library eBook service in new media development and plays a leading role of the industry.

\section{References}

Analysys Yiguan. (2015). 2015 Theme research in China Mobile reading Market. Retrieved November 20, 2016 at http://www.analysys.cn/view/search/search.html?keyword=中国移动阅读市场专题研究报告 2015. [In Chinese]

Fu, Y. A. and Huang, X.B. (2012). OverDrive Solutions for Library Mobile Reading and Its Features. Library Journal, 31(2), 64-68. Retrieved November 7, 2016 at http://www.cnki.com.cn/Article/CJFDTOTALTNGZ201202015.htm. [In Chinese]

He, M. Q. and Fu, W. Q. (2015). Analysis of Library E-Book Lending Service Status in Australia, Library, November 2015, 65-69. Retrieved November 7, 2016 at http://www.airitilibrary.com/Publication/alDetailedMesh?DocID=tusg201511015. [In Chinese]

Li, Y. (2015). An Empirical Study on the Effect of the Public Library's Popular EBook Service. Library Journal, 34(11), November 2015, 24-28. doi: 10.13663/j.cnki.lj.2015.11.004. [In Chinese]

Price, G. (2015). Six month review of public library e-Lending pilot in UK published. Library Journal, November 24, 2015. Retrieved November 19, 2016 at http://www.infodocket.com/2014/11/24/six-month-review-of-publiclibrary-e-lending-pilot-in-uk-posted/.

Shanghai Library. (2015). Brief history. Retrieved November 19, 2016 at http://www.library.sh.cn/Web/news/aboutus/index.html.

Shen, H. (2015), Practices of eBooks Service of "Window of Shanghai”, Library Journal, 34 (7), 41-45. doi: 10.13663/j.cnki.lj.2015.07.007. [In Chinese]

Sieghart, W. (2013). An independent review of E-lending in public libraries in England. Department for Culture, Media and Sport. Retrieved November 19, 2016 at http://www.alcs.co.uk/Documents/ELending-Review-March2013.aspx.

Sootoo Institute. (2015). Report of 2015 Q3 mobile reading market. Retrieved November 20, 2016 at http://www.sootoo.com/content/658519.shtml. [In Chinese]

The Publishers Association. (2015). The Society of Chief Librarians and The Publishers Association Report on the remote Ebook Lending Pilots. Retrieved November 19, 2016 at http://publishers.org.uk/EasySiteWeb/GatewayLink.aspx?alId=18916.

The State Council Information Office of the People's Republic of China. (2009). Introduction to Shanghai. Retrieved November 19, 2016 at http://www.scio.gov.cn/ztk/dtzt/07/03/Document/485318/485318.htm. [In Chinese]

Wei, L. and Liu, X. (2015). A Comparative Study of Ebook Service in Chinese and American Libraries, Library and Information Service, 59 (4), 56-62. doi: 10.13266/j.issn.0252-3116.2015.04.009. [In Chinese]

Zhang, L. (2015). Metadata Integration Platform for Library's Digital Reading Services. Library Journal, 34 (11), 1317. doi: 10.13663/j.cnki.lj.2015.11.002. [In Chinese]

Zhang and Zhang. (2015) The twelfth national reading survey report is published - a new reading style is forming. Retrieved November 20, 2016 at 
http://www.cssn.cn/zt/zt_xkzt/zt_wxzt/2015sjdsr/sjdsrzqmyd/201504/t20150422_1596633.shtml. [In Chinese]

\section{About the author}

Qing Zhou is Librarian at the International Cooperation Division of Shanghai Library. 